\title{
Social and environmental factors in the diversity of tomato landraces from the South-Central region of Mexico
}

\section{Yolanda del Rocio Moreno-Ramírez ${ }^{1}$ iD Aurelio Hernández-Bautista ${ }^{1}$ (D) Porfirio Ramírez-Vallejo ${ }^{1}$ Fernando Castillo-Gónzalez ${ }^{1}$ (D) Mario Rocandio-Rodríguez ${ }^{2 *}$ (iD) Venancio Vanoye-Eligio ${ }^{2}$ (iD Sandra Grisell Mora-Ravelo ${ }^{2}$ iD}

${ }^{1}$ Postgrado en Genética. Colegio de Postgraduados (COLPOS), Campus Montecillo, Texcoco, Edo. de México, México. ${ }^{2}$ Instituto de Ecología Aplicada, Universidad Autónoma de Tamaulipas (UAT), División del Golfo 356, C.P. 87019, Col. Libertad, Cd. Victoria, Tamaulipas, México. E-mail: mrocandio@docentes.uat.edu.mx. "Corresponding autor.

ABSTRACT: In the present study, we investigated the influence of social and environmental factors in the genetic diversity of tomato landraces in the South-Central region of Mexico. A total of 30 tomato landraces, collected in 18 villages with different ethnolinguistic affiliations, were analyzed. We reported that the genetic diversity of tomato landraces is associated with the ethnolinguistic group, weather, and soil-type present in the region studied. Our results showed that there are morphological differences between landraces grown by different ethnolinguistic groups; however, there was also evidence of morphological similarities between landraces from groups with different ethnolinguistic affiliations. Finally, different selection criteria, mainly fruit color, size and shape, plays an important role in the phenotypic divergence among landraces grown in different traditional farming systems.

Key words: ethnolinguistic diversity, native populations, weather, elevation, soil.

Influência de fatores sociais e ambientais na diversidade de variedades crioulas de tomateiro da região Centro-Sul do México

RESUMO: No presente estudo investigamos a relação da afiliação etnolinguística com a diversidade genética de variedades locais de tomate na região Centro-Sul do México. Um total de 30 variedades de tomate, coletadas em 18 aldeias com diferentes afiliações etnolinguísticas, foram analisadas. Verificamos que a diversidade genética das variedades crioulas de tomate está associada ao grupo etnolinguístico presente na região estudada. Nossos resultados mostram que existem diferenças morfológicas entre raças cultivadas por diferentes grupos etnolinguísticos. No entanto, também houve evidências de semelhanças morfológicas entre raças de grupos com diferentes afiliações etnolinguísticas. Finalmente, diferentes critérios de seleção, como, principalmente, cor, tamanho e forma dos frutos, desempenham um papel importante na divergência fenotípica entre as variedades crioulas cultivadas em diferentes sistemas agricolas tradicionais.

Palavras-chave: Diversidade cultural, População nativa, Variabilidade fenotípica, Variedades de tomate.

\section{INTRODUCTION}

The genetic variability present in Mesoamerica and the Andes regions is broader than that observed in the European cultivars (VILLAND et al., 1998). Specifically, in the Central and Southern regions of Mexico, wide phenotypic diversity in fruit size and shape has been observed in natural populations including wild populations (ÁLVAREZ-HERNÁNDEZ et al., 2009) and cultivated landraces (AGUILAR \& MONTES, 1993). Diversity in shapes, colors and sizes of tomato fruit as well as the commercial quality observed in the native germplasm was reported to be an attractive source of genes with high agronomic importance for breeding programs.

Although, the genetic diversity of landraces and their breeding potential is well known (CARRILLO-RODRÍGUEZ \& CHÁVEZ-SERVIA, 2010; ESTRADA-CASTELLANOS et al., 2011), information about the impact of ethnolinguistic effects on tomato diversity is yet limited.

The use and management of native varieties satisfy multiple objectives and impact the biological, economic, and cultural plurality of traditional agrosystems (CAMACHO et al., 2006). These systems, besides being notably diverse, promote and conserve genetic resources and define 
domestication processes (ENJALBERT et al., 2011). Today, tomato landraces form part of production systems in a broad spectrum of ecosystems (SÁNCHEZ-PEÑA et al., 2006).

These landraces are cultivated in traditional gardens for home use and for sale in local and regional markets (DEL ÁNGEL-PÉREZ \& MENDOZA, 2004). The process of fruits selection based on a few attributes, especially fruit size and shape (GRANDILLO et al., 1999), for obtaining seeds has caused genetic differentiation among populations grown by farmers. The objective of the present study was to understand how the ethnolinguistic, weather, soil-type and elevation factors influenced the phenotypic diversity of tomato landraces cultivated by farmers affiliated with different ethnolinguistic groups.

\section{MATERIALS AND METHODS}

The sampled villages were located in the South-Central region of Mexico that is considered part of the Mesoamerican region of Mexico. The study was performed in 18 villages (Figure 1). The altitudinal gradient of the study area ranged from 10 to 2199 meters above sea level (m.a.s.1.).

The altitude was classified in three categories; low (0 - 800 m.a.s.1.), middle (801-1600 m.a.s.1.) and high (1601-2200 m.a.s.1.). According to the Köppen classification modified by GARCÍA (1988), the region studied was characterized by 7 different climates: (A)cf, $\mathrm{Cw}_{2} \mathrm{~b}^{\prime}$, Aw, Aw1, $\mathrm{A}(\mathrm{C})$ $\mathrm{w}_{1}, \mathrm{Cw}_{1} \mathrm{~b}^{\prime}$ and $\mathrm{Bs}_{1}$. The information about soil type of each sampled site was obtained from database of CONABIO (2019). The study included a total of 5 different ethnolinguistic groups. Specifically, we visited the north region of Puebla State, characterized by the Náhuatl language; an interstate region located between Puebla and Hidalgo states, where two different ethnolinguistic groups (Náhuatl and Otomí) were established; the center-west region of Oaxaca State, where the Zapoteco indigenous language is more predominant; the Central region of Guerrero State, characterized by the indigenous language Mexicano; and the Southeast region of Mexico, comprising the states of Campeche and Yucatan, where the language Maya is still spoken.

The sampling strategy was based on fields and traditional gardens from 18 villages in the South Central region of Mexico. Local farmers were contacted by the village heads to determinate the sampled site inside of each village. In each village, the number of visited household ranged from one to three households per village, giving a total of 30 farmers surveyed. The interview was conducted to know their criteria for seed selection, common use of

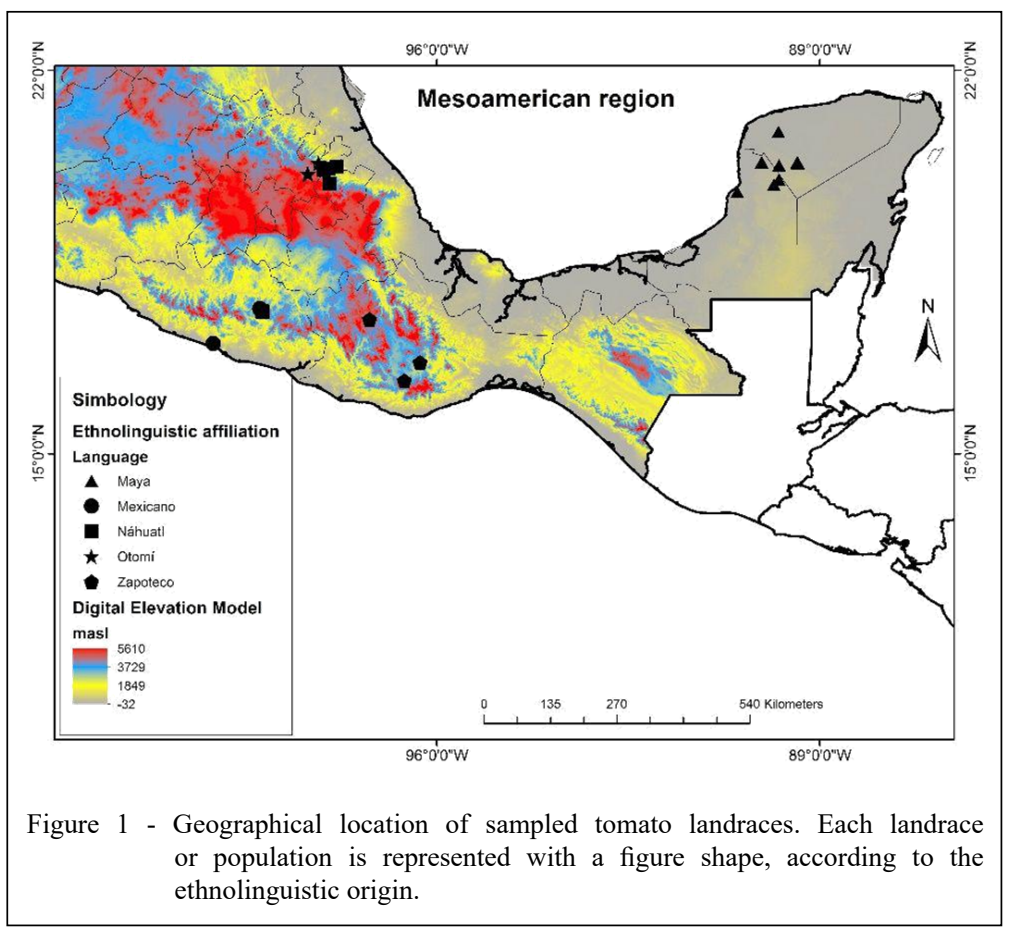

Ciência Rural, v.49, n.5, 2019. 
fruits and obtaining seed. Of each farmer surveyed, we obtained on composited sample which represented one population. Therefore, a total of 30 samples or populations were obtained from 18 villages. We obtained a composited sample of $6 \mathrm{~kg}$ of fruits and 60 flowers collected from a total of 50 plants randomly chosen. The number of fruits per sample ranged from 40 large fruits to 240 small fruits. In situ observations were made from 2012-2014. Finally, the identification of landraces was determined by the information given by the local farmers and previous research performed in the study area.

Morphological descriptions were made based on the 14 characteristics. These variables were grouped into two categories: i) Flower traits: number of petals (mm, NP), length of petals $(\mathrm{mm}$, LP), number of sepals (mm, NS), length of sepals (mm, LS), length of staminal column (mm, LSC) and length of the flower style (mm, LFS); and ii) Fruit size and shape traits: chroma (Chr), luminosity (LM), hue $(\mathrm{FH})$, average fruit weight (g, WF), fruit diameter (mm, FD), fruit length (mm, FL), pericarp thickness (mm; PTk), locule number (LN) and fruit shape index (relationship diameter/length). Color-related traits were measured using the Hunter $\mathrm{Lab}^{\mathrm{TM}}$ colorimeter (model ColorFlex EZ, VA, USA), where the parameters $L^{*}, a^{*}$ and $b^{*}$ were obtained and evaluated in the equatorial zone and the distal end. Using these parameters, the estimation of fruit chroma, hue and luminosity were performed according to the procedure suggested by DARRIGUES et al. (2008).

To know if factors such as ethnolinguistic grouping, weather and elevation influence the tomato morphological diversity, a permutational multivariate analysis of variance was performed. The permutational multivariate analysis of variance was performed using the package vegan (OKSANEN et al., 2015) developed for the R statistical program (R CORE TEAM, 2014). This non-parametric test consists of partitioning the distance matrix in sources of variation (ANDERSON, 2001). For this analysis, we set 10,000 permutations to estimate the F statistics and used a significance level of 0.01 to reject the null hypothesis.

Population structures based on floral and fruit traits were measured by principal components analysis (PCA) and hierarchical clustering. These two tests were employed separately for each set of variables (flower or fruit traits) and combined all variables. For PCA, data were centered by subtracting the mean from each variable in each observation and dividing by the standard deviation. For the hierarchical clustering analysis, similarity relationships among the
30 populations were established with the Euclidian distances, and the hierarchical clusters were defined by the unweighted pair group method with the arithmetic mean (UPGMA). Determination of clusters was supported with the statistical criteria AP $p$ value (SHIMODAIRA, 2004).

For each cluster, a $p$ value was calculated via a multiscale bootstrap analysis with 1000 bootstraps and $\alpha=0.05$. A multiscale bootstrap analysis was performed using the average method and correlation-based dissimilarity matrix, using the pvclust package (SUZUKI \& SHIMODAIRA, 2006). Finally, we employed a Tukey test $(\alpha=0.05)$ to detect the main causes of the phenotypic divergence observed among the landraces grown within each geographic region.

\section{RESULTS}

According to the results, the most of growers obtain the seed of own production and their agricultural production is for own consumption (Table 1). However, different selection criteria are used by growers during the selection of fruits. In general, all growers use the fruit shape as criteria selection of fruits. Additionally, it was observed that exocarp thickness, color and difficult to remove the exocarp are others criteria frequently used by growers with ethnolinguistic affiliation Náhuatl and Otomí. In contrast, growers speaking Maya and Zapoteco consider the firmness as an important criterion during the selection of fruits.

For a full understanding of the effects of social and ecological factors in structuring populations, a permutational multivariate analysis of variance was performed with a significance level of 0.05 . The permutational multivariate analysis of variance showed that the ethnolinguistic, weather and soil-type effects were significant in the combined, flower and fruit traits analyses $(\mathrm{P}<0.01)$ (Table 2).

According to the sum of squares and coefficient of determination $\left(\mathrm{R}^{2}\right)$, the ethnolinguistic factor had a greater effect than the weather. These results indicated that the ethnolinguistic diversity played a more important role in structuring morphological diversity in the studied region.

To understand the links between the morphovariability of tomato fruit and ethnolinguistic, weather and soil-type effects, a PCA and clustering analysis was performed on morphological traits (Figure 2 and 3). Based on the combined analysis, the linear combination of the 15 traits explained nearly $48 \%$ of the phenotypic variability 
Table 1 - General description of the selection criteria used by growers, use of production and seed source.

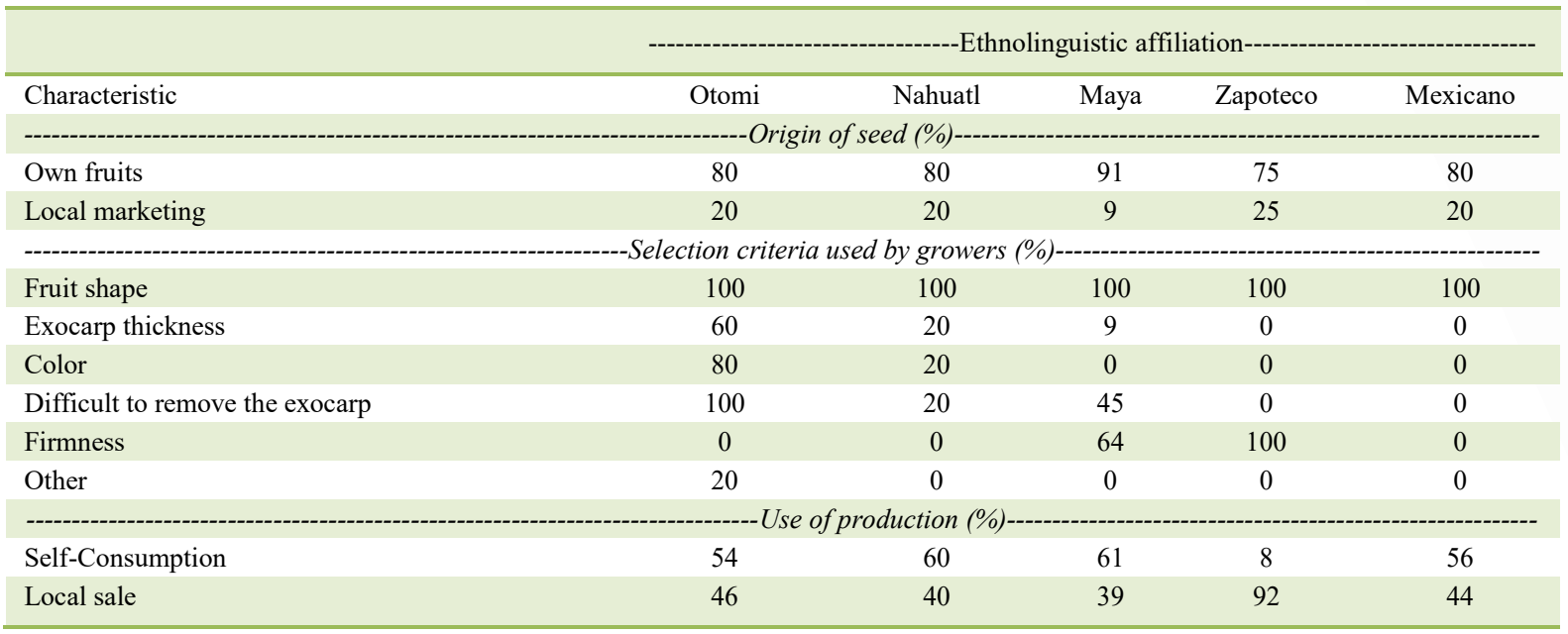

through the first two PCs (Figure 2A). The first component divided the populations according to the size and number of floral structures, whereas the second component grouped the landraces by fruit size. Specifically, the number of petals and sepals, length of petals and sepals and locule number were the attributes that most contributed to determination of the first component. The second component was

Table 2 - Permutational multivariate analysis of variance for fruit and flower traits.

\begin{tabular}{|c|c|c|c|c|c|c|}
\hline SV & Df & Sum of squares & Mean squares & $\mathrm{F}$ & $\mathrm{R}^{2}$ & $\operatorname{Pr}(>F)$ \\
\hline \multicolumn{7}{|c|}{ 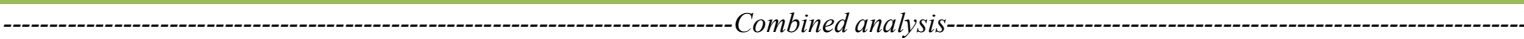 } \\
\hline Ethnolinguistic affiliation & 4 & 0.48734 & 0.12184 & 32.547 & 0.51926 & 0.0001 \\
\hline Elevation & 2 & 0.00829 & 0.00414 & 1.107 & 0.00883 & 0.3509 \\
\hline Weather & 4 & 0.04156 & 0.01039 & 2.775 & 0.04428 & 0.0025 \\
\hline Soil type & 7 & 0.13182 & 0.018831 & 5.031 & 0.14045 & 0.0001 \\
\hline Residuals & 72 & 0.26952 & 0.00374 & & 0.28718 & \\
\hline Total & 89 & 0.93853 & & & 1 & \\
\hline \multicolumn{7}{|c|}{ 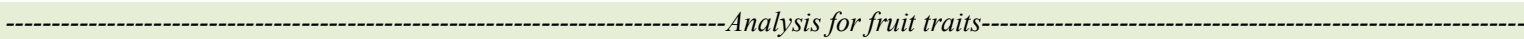 } \\
\hline Ethnolinguistic affiliation & 4 & 0.73808 & 0.18452 & 37.011 & 0.55429 & 0.0001 \\
\hline Elevation & 2 & 0.00875 & 0.00437 & 0.877 & 0.00657 & 0.482 \\
\hline Weather & 4 & 0.05284 & 0.01321 & 2.649 & 0.03968 & 0.0071 \\
\hline Soil type & 7 & 0.17296 & 0.02471 & 4.956 & 0.12989 & 0.0001 \\
\hline Residuals & 72 & 0.35896 & 0.00499 & & 0.26958 & \\
\hline Total & 89 & 1.33159 & & & 1 & \\
\hline \multicolumn{7}{|c|}{ - } \\
\hline Ethnolinguistic affiliation & 4 & 0.05152 & 0.01288 & 7.9269 & 0.21123 & 0.0001 \\
\hline Elevation & 2 & 0.00648 & 0.00324 & 1.9939 & 0.02657 & 0.0845 \\
\hline Weather & 4 & 0.02382 & 0.00595 & 3.664 & 0.09763 & 0.0006 \\
\hline Soil type & 7 & 0.04511 & 0.00644 & 3.9655 & 0.18492 & 0.0001 \\
\hline Residuals & 72 & 0.117 & 0.00163 & & 0.47965 & \\
\hline Total & 89 & 0.24393 & & & 1 & \\
\hline
\end{tabular}




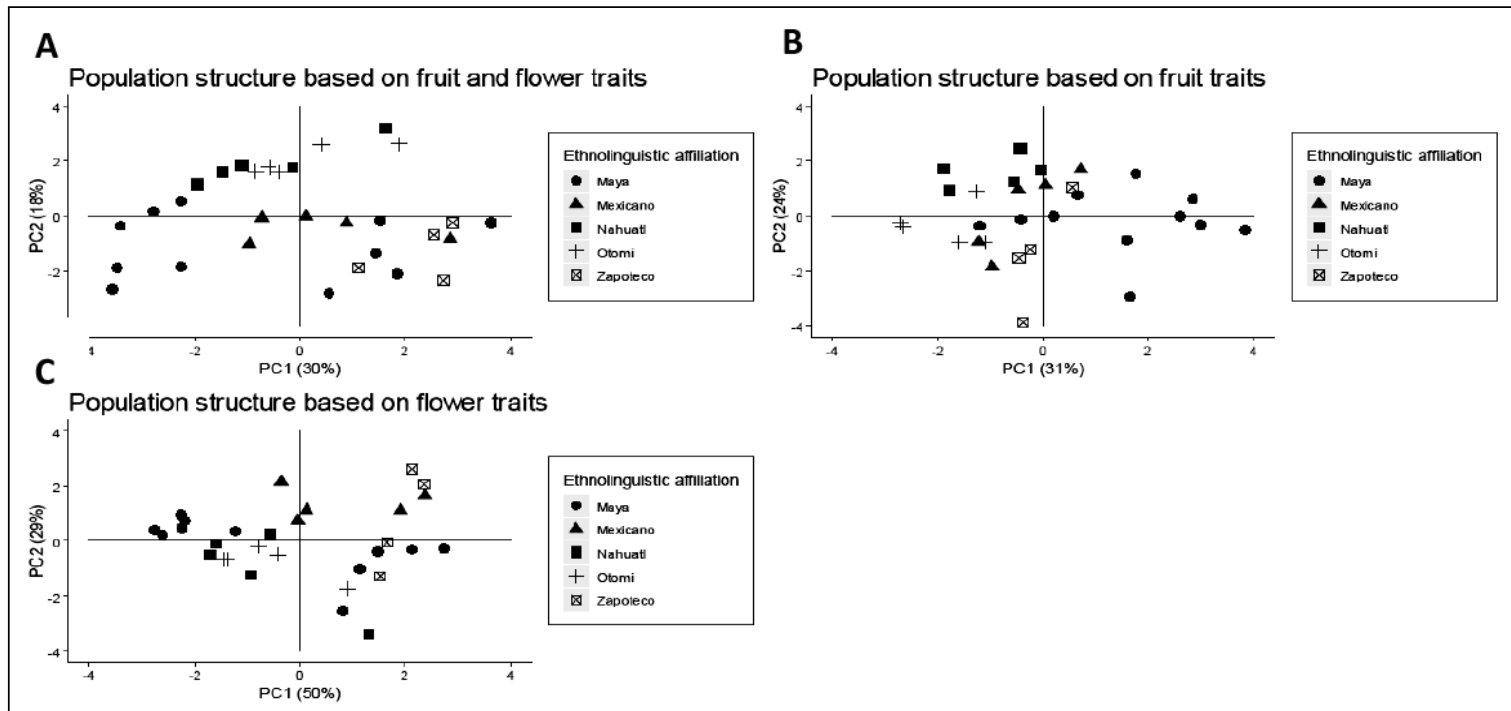

Figure 2 - Population structure of tomato landraces based on the combined analysis of fruit and flower traits (A), analysis of fruit traits (B), and analysis of flower traits (C).

associated with the average fruit weight, fruit length, fruit shape index and pericarp thickness. Based on the AP $p$ value criteria, the clustering analysis grouped the landraces into two sets (Figure 3A). With the exception of one landrace, the grouping of each landrace was associated with their ethnolinguistic origin. In the PCA performed exclusively with fruit traits, the first two principal components explained about $55 \%$ of the total variation. The first component alone (PC1) accounted for $31 \%$ of the total variation, and the second component (PC2) accounted for $24 \%$ of the variation (Figure 2B). The first component was positively associated with fruit diameter, fruit length, and luminosity and was negatively associated with fruit shape index. The second component (PC2) was positively correlated with locule number and negatively correlated with average fruit weight, pericarp thickness, hue, and chrome. According to the results of the clustering analysis, the two main geographic groups were distinguished in the study population (Figure 3B). The first region (1) was formed mostly by the states of Puebla and Hidalgo, whereas the landraces located in the Southern central region belonged to the states of Guerrero, Oaxaca, Campeche, and Yucatan. The populations of the first region were shown to have fruits with small size and a semi-spherical shape. In contrast, the populations belonging to region 2 showed heavy fruits with large size and with a very thick pericarp (Table 3 ).
Additionally, the cluster analysis identified two and four subgroups from regions 1 and 2, respectively. For region 1, the first subgroup, or ecological niche, was formed by villages in the municipalities of Jopala and Zacatlan of Puebla State, whereas the second ecological niche was in villages located between the geographic limits of Puebla and Hidalgo. Regarding region 2, the first subgroup was represented by a major proportion of populations from the state of Guerrero, the second subgroup by villages from Yucatan and Campeche, and the third and fourth subgroups by villages from the states of Yucatan and Oaxaca.

Population structuring, revealed by PCA performed with floral structures, did not show a relationship with cultural diversity (Figure $2 \mathrm{C}$ ). The first and second components explained $79 \%$ of the total variance. Length of petals, pals and staminal columns were the attributes that most contributed to the first component, which explained $50 \%$ of the total variation. The second component explained $29 \%$ of the variation and was characterized by the number of petals, number of sepals and length of pistil scar. Cluster analysis produced results similar to those of the PCA. The landraces were divided into seven clusters (Figure 3C). Interestingly, such clusters did not show differences with respect to the length of the stamina column and length of the flower style.

Comparisons between means for two regions are provided in table 3. Results of the Tukey 


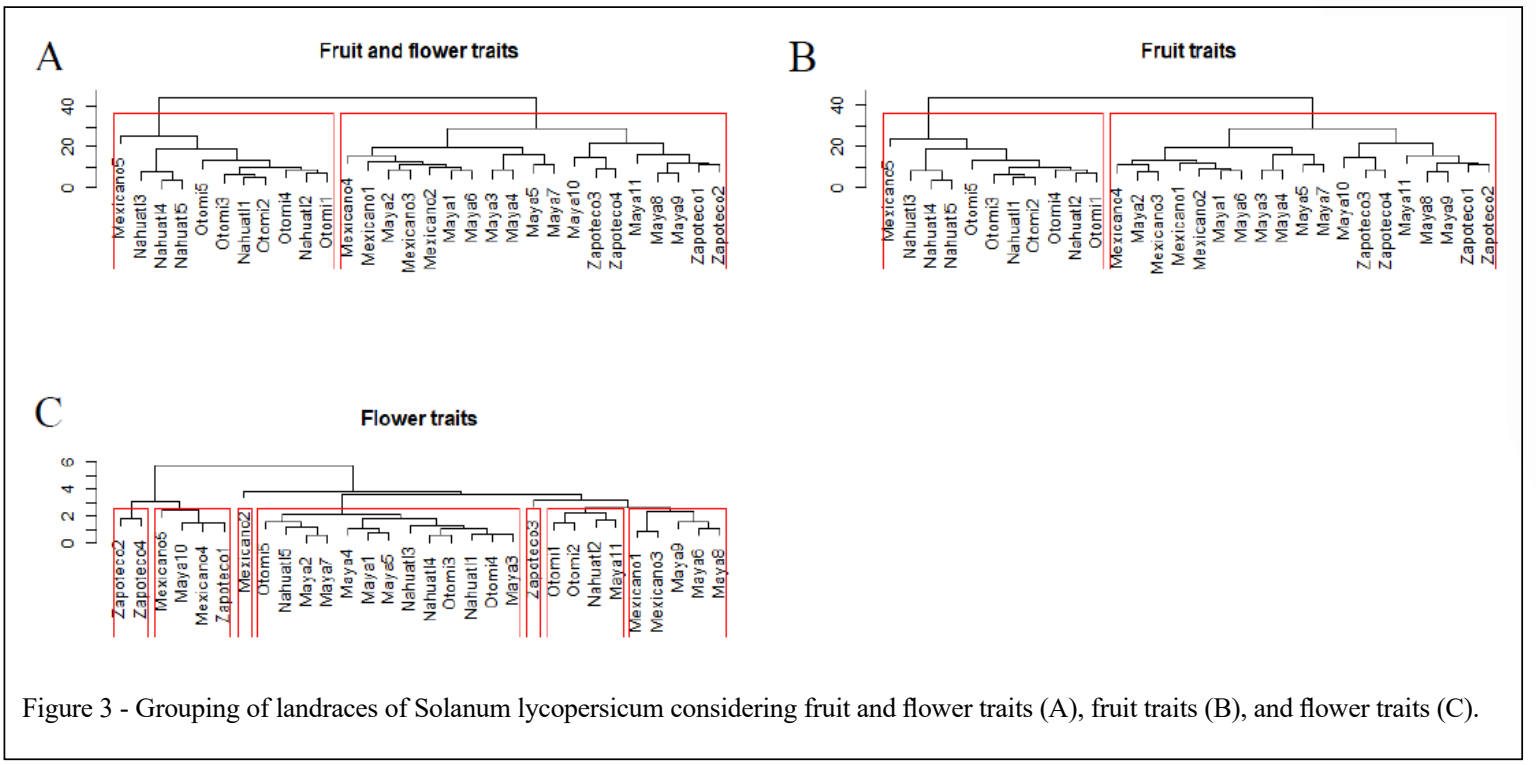

test indicated that the phenotypic differentiation between the two geographic regions was due to significant differences $(p<0.05)$ between average fruit weight, fruit diameter, fruit length, pericarp thickness and fruit shape index. Specifically, in the Southern region, we reported fruits with a larger size and a much greater weight in comparison to the fruits collected in the Central region.

\section{DISCUSSION}

Genetic diversity in crops is affected by environmental, social and genetic factors (PERALES et al., 2005; HEERWAARDEN et al., 2010). In particular, BRUSH \& PERALES (2007) argued that the social factor plays an important role in the maintenance of particular landraces in specific ecological niches. Additionally, VIGOUROUX et al. (2008) and VAN HEERWAARDEN et al. (2011) observed that maize diversity is associated with elevation, suggesting that elevation is an important factor affecting the population structure of maize landraces. Our results showed that the ethnolinguistic, weather and soil-type factors were more important for explaining the tomato diversity than the altitude. However, ethnolinguistic affiliation played the more important role in the population diversity of tomato landraces than the rest of factors. These results suggested that the population diversity of tomato landraces is strongly affected by the ethnolinguistic diversity present in the Mesoamerican region of Mexico. Our results are in agreement with those reported by OROZCO-RAMÍREZ et al. (2016), who, in their research performed on maize, showed that social factors are more important in the gene flow than the elevation was.

HAYDAR et al. (2007) argued that the flower and fruit characteristics were the main attributes manipulated during the tomato domestication process. However, it is not clear how these two traits have affected the population structure of the tomato landraces planted in the Mexican Mesoamerican region. For this reason, a principal components analysis and cluster analysis were performed on floral and fruit traits. These analyses showed that fruit size of tomato was distributed in two regions in Mexico, namely Central and Southern, with the Southern region covering the largest geographical area. The landraces were grouped according to their ethnolinguistic affiliation. In contrast, the first two principal components and clustering analysis, based on flower structure traits, did not group the landraces according to their social origin. These results indicated that the tomato variability based on fruit traits is strongly influenced by cultural grouping. The main reason of this association could be the selection criteria used by local farmers for choosing seed. Based on the information from farmers in the study region and from RÍOS-OSORIO et al. (2013), the farmers choose the seed according to some agronomic 
Table 3 - Comparison of groups detected by the clustering analysis under UPGMA criteria.

\begin{tabular}{|c|c|c|c|c|c|c|c|c|}
\hline \multirow{3}{*}{ Trait } & \multicolumn{3}{|c|}{-------Cluster 1 ${ }^{\mathrm{a}}$--------- } & \multicolumn{3}{|c|}{---------Cluster 2--------- } & \multicolumn{2}{|c|}{------------General---------- } \\
\hline & \multirow[b]{2}{*}{ Mean } & & \multirow[b]{2}{*}{ SD } & \multirow[b]{2}{*}{ Mean } & & \multirow[b]{2}{*}{ SD } & \multicolumn{2}{|c|}{----------Population-------- } \\
\hline & & & & & & & Mean & SD \\
\hline \multicolumn{9}{|c|}{ } \\
\hline Average fruit weight (g) & 16.62 & $\mathrm{~b}^{\mathrm{b}}$ & 5.58 & 55.33 & a & 12.59 & 41.14 & 21.66 \\
\hline Locule number & 6.09 & & 0.77 & 6.00 & & 1.44 & 6.03 & 1.22 \\
\hline Fruit diameter (mm) & 40.13 & $\mathrm{~b}$ & 9.20 & 47.91 & a & 7.67 & 45.06 & 8.96 \\
\hline Fruit length (mm) & 25.70 & $\mathrm{~b}$ & 4.71 & 35.22 & $\mathrm{a}$ & 8.05 & 31.73 & 8.35 \\
\hline Pericarp thickness (mm) & 4.44 & & 0.69 & 5.17 & & 1.21 & 4.90 & 1.10 \\
\hline Luminosity & 30.45 & & 2.60 & 30.78 & & 2.45 & 30.66 & 2.46 \\
\hline Hue & 0.56 & & 0.08 & 0.56 & & 0.12 & 0.56 & 0.10 \\
\hline Chroma & 20.51 & & 1.80 & 21.05 & & 2.56 & 20.86 & 2.29 \\
\hline Fruit shape index & 1.58 & $\mathrm{a}$ & 0.15 & 1.40 & $\mathrm{~b}$ & 0.22 & 1.46 & 0.22 \\
\hline \multicolumn{9}{|c|}{ 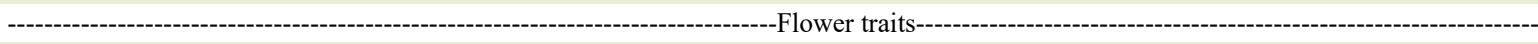 } \\
\hline Number of sepals & 7.14 & & 0.62 & 6.81 & & 0.65 & 7.00 & 0.65 \\
\hline Number of petals & 7.17 & & 0.64 & 6.80 & & 0.64 & 7.01 & 0.66 \\
\hline Length of petals (mm) & 16.52 & & 1.38 & 16.40 & & 1.77 & 16.47 & 1.53 \\
\hline Length of sepals (mm) & 13.45 & & 2.11 & 13.55 & & 2.29 & 13.50 & 2.15 \\
\hline Length of the flower style (mm) & 10.19 & & 0.84 & 10.36 & & 0.79 & 10.26 & 0.81 \\
\hline Length of staminal column (mm) & 9.81 & & 0.88 & 9.65 & & 0.53 & 9.74 & 0.74 \\
\hline
\end{tabular}

${ }^{\text {a }}$ grouping based on the combined analysis.

${ }^{\mathrm{b}}$ Groups sharing the same letter are not statistically different, using $p<0.05$ for the Tukey test.

requirements, such as the fruit size, shape, color, and health. Therefore, fruits exhibiting a specific shape and excellent health are preferred for seed. Such selection criteria reported in our study is consistent with that reported by TANKSLEY (2004) and BAI \& LINDHOUT (2007), who argument that the fruit has been the main biological selection criterion used by early farmers since the tomato domestication. The main reason to use the fruit as the selection criterion during the domestication process was because the extracted seed from large fruits resulted in cultivars with larger fruits; this situation led to reductions in the harvesting time (TANKSLEY, 2004).

Seed exchange of traditional tomato is a practice that is commonly utilized by farmers in different regions of Mexico (ESTRADACASTELLANOS et al., 2011; RÍOS-OSORIO et al., 2013). In the present study, the clustering analysis identified two main groups, but several subgroups were also observed within each of the main groups. Some subgroups were formed exclusively by landraces from one specific ethnic group; however, there were also subgroups consisting of a mixture of landraces with different social origins. In particular, in the Central region, two subgroups were observed; one subgroup was formed by landraces grown by farmers speaking the language Náhuatl, and the other subgroup was formed from a mixture of landraces with different cultural origins (Náhuatl and Otomí). The combined grouping reported in the Central region was due to the fact that the landraces were located in a geographic area where the Náhuatl and Otomí villages were close to each other; therefore, it is highly probable that seed was exchanged. In this sense, RIOS-OSORIO et al. (2013) provided proofs that traditional farmers from a region of Oaxaca obtain their native tomato seed in the local markets where many farmers from different villages converge to offer their fruits. Therefore, it is highly probable that the seed exchange between farmers with similar or different ethnolinguistic origins may happen. Concerning to the Southern region, most of the subgroups were formed of landraces from villages located in the Maya region. However, it is not possible conclude that these different ethnolinguistic affiliations (Maya, Mexicano and Zapoteco) showed a possible interaction due to the wide distance between the sampling points. All previous results are in agreement to those reported by JIKA et al. (2017), who studying the ethnolinguistic 
effect on the pearl millet diversity in the Lake Chad Basin, reported that different ethnolinguistic affiliation causes a limited gene flow between landraces within one specific region. However, they also observed in other regions that there was marked gene flow between populations grown by different ethnolinguistic groups.

\section{CONCLUSION}

Morphological diversity of tomato landraces due to floral and fruits traits is more strongly influenced by the ethnolinguistic grouping than by differentiation in environmental factors.

\section{ACKNOWLEDGEMENTS}

To CONACyT for the support provided for the realization of the present investigation through the project of Integral Assessment of the Diversity of Native Populations of Mexican Jitomate, led by Dr. Porfirio Ramirez Vallejo

\section{DECLARATION OF CONFLICT OF INTERESTS}

The authors declare no conflict of interest. The founding sponsors had no role in the design of the study; in the collection, analyses, or interpretation of data; in the writing of the manuscript, and in the decision to publish the results.

\section{AUTHORS' CONTRIBUTIONS}

Moreno-Ramírez, Y.d.R., Hernández-Bautista, A. performed the experiment, analyzed data and wrote the paper; Ramírez-Vallejo P. analyzed data and wrote the paper; RocandioRodríguez, M. planned the research, designed and performed the experiment, analyzed data and wrote the paper; Castillo-González, F., Vanoye-Eligio, V. analyzed data and critically reviewed the paper; Mora-Ravelo, S.G. critically reviewed the paper. The final version of the manuscript was reviewed and approved by all authors.

\section{REFERENCES}

AGUILAR, S.M.; MONTES, S.H. Recolección de germoplasma de Capsicum, Cucurbita y Lycopersicon en México. In: CLAUSEN A. M., E. CAMADRO L., A. LOPEZ-CAMELO F.Y A. HUARTE M. (Eds.). Actas del II Simposio Latinoamericano sobre Recursos Genéticos de Especies Hortícolas, Argentina. p.53-82. 1993. Available from: $<$ http://www.fao.org/pgrfa-gpa-archive/arg/argentina. pdf $>$. Accessed: Jan. 20, 2016.

ÁLVAREZ-HERNÁNDEZ, J.C.; et al. Exploración y caracterización de poblaciones silvestres de jitomate (Solanaceae) en tres regiones de Michoacán, México. Polibotánica, v.28, p.139159. 2009. Available from: <http://www.scielo.org.mx/pdf/polib/ n28/n28a7.pdf $>$. Accessed: Jun. 21, 2016.

ANDERSON, M.J. A new method for non-parametric multivariate analysis of variance. Austral Ecology, v.26, p.32-46. 2001.
Available from: <http://doi:10.1111/j.1442-9993.2001.01070. pp.x>. Accessed: Jul. 16, 2016. doi: 10.1111/j.14429993.2001.01070.pp.x.

ÁNGEL-PÉREZ,A.L.D.; MENDOZA, M.A. Totonac homegardens and natural resources in Veracruz, México. Agriculture and Human Values, v.21, p.329-346. 2004. Available from: <http:// doi.org/10.1007/s10460-004-1219-9>. Accessed: Mar. 1, 2017. doi: 10.1007/s10460-004-1219-9.

BRUSH, S.; PERALES, H. A maize landscape: Ethnicity and agro-biodiversity in Chiapas Mexico. Agriculture Ecosystems \& Environment, v.121, p.211-221. 2007. Available from: <http:// doi:10.1016/j.agee.2006.12.018>. Accessed: Jan. 25, 2015. doi: 10.1016/j.agee.2006.12.018.

CAMACHO, V.T.C; et al. Defining and identifying Crop Landraces. Plant Genetics Resourses, v.3, p.373-384. 2006. Available from $<$ http://doi:10.1079/PGR200591>. Accessed: Oct. 19, 2016. doi: 10.1079/PGR200591.

CONABIO. COMISIÓN NACIONAL PARA EL CONOCIMIENTO Y USO DE LA BIODIVERSIDAD, Mexico, Mexico. 2019. Available from: <https://www.conabio.gob.mx>. Accessed: Jun. 11, 2016.

DARRIGUES, A.; et al. Tomato analyzer-color test: a new tool for efficient digital phenotyping. Journal of the American Society for Hortcultural Science, v.133, p.579586.2008. Available from: <https://vanderknaaplab.uga.edu/ files/Darrigues_et_al_2008-TA_Color_Test-JASHS.pdf $>$. Accessed: Dec. $12, \overline{2} 015$.

ENJALBERT, J.; et al. Dynamic management of crop diversity: From an Experimental Approach to on-farm conservation. Comptes Rendus Biologies, v.334, p.458-468. 2011. Available from: <http://doi:10.1016/j.crvi.2011.03.005>. Accessed: Oct. 22, 2016. doi: 10.1016/j.crvi.2011.03.005.

ESTRADA-CASTELLANOS, J.B.; et al. Small farmer practices for production improvement of the kidney-type tomato landrace: A case study in Oaxaca. African Journal Agricultural Research, v.6, p.3176-3182. 2011.

GARCÍA, E. 1988. Modificaciones al sistema de clasificación climática de Köppen. Ed. Universidad Nacional Autónoma de México, México.

GRANDILLO, S.; et al. Identifying the loci responsible for natural variation in fruit size and shape in tomato. Theoretical and Applied Genetics, v.99, p.978-987. 1999. Available from: <http:// doi.org/10.1007/s001220051405>. Accessed: Oct. 09, 2016. doi: $10.1007 / \mathrm{s} 001220051405$.

HAYDAR, A.; et al. Studies on Genetic Variability and Interrelationship among the Different traits in Tomato. Middle-East Journal of Scientific Research, v.2, p.139-142. 2007. Available from: <https://pdfs.semanticscholar.org/0461/ f55476274c4d4f670cf366cfcb7d4238b193.pdf. Accessed: Sep. 18, 2016.

JIKA, A.N.; et al. Unexpected pattern of pearl millet genetic diversity among ethno-linguistic groups in the Lake Chad Basin. Heredity, v.118, p.1-12. 2017. Available from: <http:// doi:10.1038/hdy.2016.128>. Accessed: Dec. 11, 2017. doi: 10.1038/hdy.2016.128 
OKSANEN, J.; et al. vegan: Community Ecology Package. R package version. 2015, 2-2. 2015.

OROZCO-RAMÍREZ, Q.; et al. Maize diversity associated with social origin and environmental ariation in Southern Mexico. Heredity, 116(5) 477-484. 2016. Available from: <http:// doi:10.1038/hdy.2016.10>. Accessed: Mar. 10, 2017. doi: 10.1038/ hdy.2016.10.

R Development Core Team, R: A language and environment for statistical computing. R Foundation for Statistical Computing, Vienna, Austria. ISBN 3-900051-07-0, 2014. Available from: $<$ http://www.R-project.org $>$. Accessed: Apr. 15, 2015.

SÁNCHEZ-PEÑA, P.; et al. Sources of resistance of whitefly (Bemisia spp.) in wild populations of Solanum lycopersicum var. cerasiforme (Dunal) Spooner G J, Anderson et R K Jansen, in Northwestern Mexico. Genetic Resourses and Crop Evolution, v.53, p.711-719. 2006. Available from: <http://doi.org/10.1007/ s10722-004-3943-9>. Accessed: Oct. 22, 2015. doi: 10.1007/ s10722-004-3943-9.

SHIMODAIRA, H. Approximately unbiased tests of regions using multistep-multiscale bootstrap resampling, The Annals of Statistics, v.32, p.2616-2641. 2004. Available from: $<$ http://doi: $10.1214 / 009053604000000823>$. Accessed: Nov. 10, 2015. doi: $10.1214 / 009053604000000823$.
SUZUKI, R.; SHIMODAIRA, H. Pvclust: an R package for assessing the uncertainty in hierarchical clustering, Bioinformatics, v.22, p.1540-1542. 2006. Available from: <http://doi:10.1093/ bioinformatics/btl117>. Accessed: Jan. 24, 2016. doi: 10.1093/ bioinformatics/btl117.

TANKSLEY, S.D. The genetic, developmental, and molecular bases of fruit size and shape variation in tomato. Plant Cell, v.16, p.S181-S189. 2004. Available from: <http://doi/10.1105/ tpc.018119>. Accessed: Mar. 29, 2016. doi: 10.1105/tpc.018119.

VAN HEERWAARDEN, J.; et al. Genetic diversity in a crop metapopulation. Heredity, v.104, p.28-39. 2010. Available from: $<$ http://doi:10.1038/hdy.2009.110>. Accessed: Mar. 17, 2016. doi: 10.1038/hdy.2009.110.

VIGOUROUX, Y.; et al. Population structure and genetic diversity of New World maize races assessed by DNA microsatellites. American Journal of Botany, v.95, p.1240-1253. 2008. Available from: <http://doi:10.3732/ajb.0800097>. Accessed: Jan. 23, 2017. doi: 10.3732/ajb.0800097.

VILLAND, J.; et al. Genetic Variation among Tomato Accesions from Primary and Secondary Centers of Diversity. Plant Genetics Resourses, v.38, p.1339-1347. 1998. Available from: <http:// doi:10.2135/cropsci1998.0011183X003800050032x>. Accessed: Jan. 18, 2017. doi: 10.2135/cropsci1998.0011183X003800050032x. 